\title{
Pembiakan Anakan (Sucker) Pisang Barangan (Musa paradisiaca L.) Secara in Vitro
}

\author{
Propagation of Barangan Banana (Musa paradisiaca L.) Sucker with In Vitro
}

\author{
Nurdin Sitohang
}

Jurusan Agronomi, Fak. Pertanian, Unika Santo Thomas Sumatera Utara Medan, Medan 20132

E-mail: unika_nurdin@yahoo.com

Pisang (Musa paradisiaca L.) termasuk Famili Musaceae, berasal dari Asia Tenggara dan tersebar di seluruh dunia. Pisang barangan sangat digemari karena rasanya enak, vitaminnya cukup, dan harganya terjangkau. Secara konvensional pisang diperbanyak dengan anakan (sucker) dan bonggol (bit), dapat dihasilkan 1-10 anakan dalam setahun (Meina, 1992). Perbanyakan pisang barangan secara in vitro dapat dilakukan untuk mendapatkan bahan tanaman yang lebih baik, khususnya yang bebas penyakit Fusarium sp dan Pseudomonas sp.

Perbanyakan in vitro digunakan untuk mengembangkan induk dengan hasil yang identik, bebas patogen, dan jumlahnya lebih banyak (Ammirato et al., 1990). Media Murashige dan Skoog (MS) digunakan secara luas sebagai media kultur jaringan, media tersebut mengandung hara makro dan mikro, kemudian diberi zat pengatur tumbuh untuk mengarahkan perkembangan kultur. Jika rasio auksin lebih tinggi dari sitokinin akan terbentuk akar, sebaliknya jika rasio auksin lebih rendah dari sitokinin akan terbentuk tunas. Beberapa zat pengatur tumbuh yang sering digunakan antara lain: asam indol asetat, asam naftalen asetat, asam indol butirat, 2,4-D (2,4-dichlorophenoxyacetic acid), kinetin, zeatin dan benzylaminopurin (Gunawan, 1987).

Pembiakan tanaman secara in vitro dibagi menjadi beberapa tahap yaitu: menyiapkan tanaman induk (tahap-0), inisiasi kultur atau culture establishment (tahap-1), multiplikasi propagul (tahap-2), pemanjangan tunas dan induksi akar (tahap-3), dan aklimatisasi plantlet (tahap-4) (Yusnita, 2003). Skema perbanyakan anakan (sucker) pisang barangan secara in vitro seperti pada Gambar 1.

\section{Menyiapkan tanaman induk sumber eksplan}

Sumber anakan dipilih dari tanaman induk yang jelas jenisnya dan terlihat sehat. Anakan sebaiknya dipelihara dahulu di rumah kaca, agar lebih sehat dan bersih dari kontaminan (Yusnita, 2003). Selama di rumah kaca, anakan (sucker) pisang barangan dipengaruhi status fisiologisnya dengan perlakuan cahaya, suhu, dan pemupukan. Anakan (sucker) dari lapangan dapat langsung dikulturkan, tetapi lebih baik digunakan anakan yang telah beradaptasi di rumah kaca selama 3 bulan (Purba, 2004).

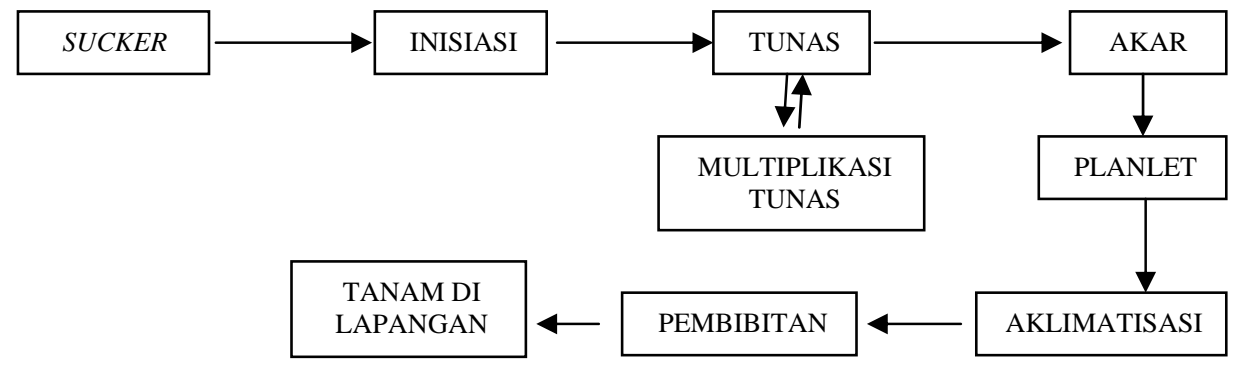

Gambar 1. Skema perbanyakan anakan pisang barangan secara in vitro 


\section{Inisiasi kultur atau culture establishment propagul}

Media MS tanpa zat pengatur tumbuh, cocok digunakan untuk inisiasi kultur pisang barangan (Sitohang, 2005). Pelepah anakan pisang dibuang, ditinggalkan pucuk dan bonggolnya, selanjutnya direndam dalam air mengalir sekitar 15 menit, kemudian dipotong sampai ukuran eksplan $\pm 2 \mathrm{~cm}^{3}$. Eksplan disterilisasi dengan alkohol $70 \%$ selama 2 menit, klorox $2 \%$ selama 5 menit, dan dibilas 5 kali dengan air steril. Secara hati-hati, eksplan diperkecil seukuran $\pm 1 \quad \mathrm{~cm}^{3}$ dengan menyertakan titik tumbuh dan bonggol, lalu segera ditanam di dalam botol kultur. Botol kultur ditutup rapat, lalu dipindahkan ke ruang inkubasi dengan suhu $25-28^{0} \mathrm{C}$. Sterilisasi dan inokulasi dilakukan di dalam LAFC (laminar air flow cabinet). Anakan dipelihara di rumah kaca selama 3 bulan, akan menghasilkan perkembangan eksplan yang sangat baik, persentase eksplan hidup mencapai 90\% dan menghasilkan tanaman lengkap (daun dan akar) sebesar 40\% (Purba, 2004). Eksplan pisang barangan yang tidak berkembang, perlu disubkultur ke media baru agar bertunas atau berakar (Limbong, 2004).

\section{Multiplikasi propagul}

Tahap ini bertujuan menggandakan propagul sesuai dengan jumlah yang diingini. Tunas lateral atau tunas adventif dirangsang dengan dua cara: pertama, dengan pembelahan eksplan secara vertikal dan kedua, dengan penggunaan zat pengatur tumbuh sitokinin khususnya benzylaminopurin (Noggle dan Fritz, 1979) atau kombinasi kedua cara diatas. Propagul yang dibelah dua lebih mudah mengalami multiplikasi dibandingkan dengan propagul yang utuh (Sitohang, 2006). Propagul disubkultur secara berulang-ulang sampai dicapai jumlah propagul yang diharapkan (Yusnita, 2003). Pada konsentrasi 2,0 mg benzylaminopurin per liter media MS, eksplan dapat menghasilkan rata-rata 7 tunas per eksplan (Silalahi, 2004), multiplikasi propagul sangat baik dengan penggunaan benzylaminopurin $5 \mathrm{mg}$ per liter media MS (Sitohang, 2008).

\section{Pemanjangan tunas dan induksi akar}

Pembentukan tunas dan induksi akar tujuannya untuk membentuk planlet memiliki daun dan akar. Tunas-tunas hasil multiplikasi dipisah satu per satu kemudian dipindahkan ke media baru yang lebih segar. Propagul pisang barangan yang telah membentuk tunas relatif mudah membentuk akar, mungkin disebabkan proses sintesis auksin endogennya cukup baik, selanjutnya asam indol asetat tersebut berperan merangsang pembentukan akar. Penambahan auksin eksogen jenis asam indol butirat sebanyak 2 mg per liter media MS cukup baik merangsang pembentukan akar pada tunas propagul (Sitohang, 2005).

\section{Aklimatisasi}

Aklimatisasi merupakan proses penyesuaian planlet pada lingkungan eksternal di luar laboratorium. Selama aklimatisasi, diatur kondisi lingkungan seperti kelembaban, suhu, dan cahaya. Plantlet ditanam pada media khusus, disungkup dengan plastik transparan, dan dibuka secara bertahap (Yusnita, 2003). Intensitas penyinaran diatur $30 \%$, media tanam terdiri dari campuran kompos, top soil dan pasir dengan perbandingan 1:1:1 atau 1:2:1 (Hutagalung, 2004). Plantlet dibersihkan, lalu direndam dalam larutan pestisida $0,2 \%$ selama 5 menit. Planlet ditanam dengan jarak antar planlet sekitar 5-8 cm, ditempatkan dalam bedengan yang diberi sungkup plastik selama 3 minggu. Plantlet yang telah tumbuh dipindahkan ke polibag berisi campuran tanah, pasir, kompos atau pupuk kandang. Bibit dalam polibag dimasukkan ke dalam sungkup selama 1 minggu, kemudian secara bertahap dibiarkan terkena sinar matahari langsung. Penyiraman dilakukan rutin pada pagi dan sore hari, penyiraman dilakukan sampai media lembab, tidak boleh terlalu basah. Pemupukan dimulai pada umur 2 minggu dengan pemberian pupuk NPK sebanyak 2 gram per polibag dan dengan larutan 0,1\% Urea melalui daun. Bibit pisang berumur 3-4 bulan akan mempunyai 4-6 daun normal, bibit ini telah dapat dipindah ke lapangan (transplanting). 


\section{Daftar Pustaka}

Ammirato, P.V., Evans, D.R., Sharp, W.R. and Bajaj, Y.P.S. 1990. Handbook of Plant Cell Culture Vol.5. Ornamental Species, McGraw Hill Book, New York.

Gunawan, L.W. 1987. Teknik Kultur Jaringan. Laboratorium Kultur Jaringan. Pusat Antar Universitas, Bioteknologi. Institut Pertanian Bogor. Bogor.

Hutagalung, M. 2004. Aklimatisasi Pisang Barangan (Musa paradisiaca L.) dalam Berbagai Komposisi Media. Skripsi. Fakultas Pertanian, Universitas Katolik Santo Thomas Sumatera Utara. Medan.

Limbong, A.M. 2004. Upaya Menumbuhkan Kultur Meristem Pisang Barangan (Musa paradisiaca L.) dengan Teknik Sub Kultur Dalam Media MS (Murashige dan Skoog). Skripsi. Fakultas Pertanian, Universitas Katolik Santo Thomas Sumatera Utara. Medan.

Meina, D. 1992. Budidaya Pisang Cavendis Asal Kultur Jaringan. Trubus No. 285, Jakarta.

Purba. 2004. Pengaruh berbagai Sumber Bibit terhadap Pertumbuhan Kultur Meristem Pisang Barangan (Musa paradisiaca L.) dengan Media Murashige dan Skoog. Skripsi. Fakultas Pertanian. Universitas Katolik Santo Thomas Sumatera Utara Medan.
Silalahi, I. 2004. Pengaruh Konsentrasi BAP dan Kinetin terhadap Multiplikasi Pisang Barangan (Musa paradisiaca L.) dalam Media Murashige dan Skoog pada Kultur Jaringan. Skripsi. Fakultas Pertanian. Universitas Katolik Santo Thomas Sumatera Utara. Medan.

Sitohang, N. 2005. Kultur Meristem Pisang Barangan (Musa paradisiaca L.) pada beberapa Komposisi Zat Pengatur Tumbuh NAA, IBA, BAP dan Kinetin dengan Media MS. $J$. Penelitian Bidang Ilmu Pertanian Kopertis Wil.I. 3 (2): 19-25.

Sitohang, N. 2006. Multiplikasi Propagul Pisang Barangan (Musa paradisiaca L.) dengan Berbagai Jumlah Tunas, dalam Media MS yang diberi BAP pada Berbagai Konsentrasi. J. Penelitian Bidang Ilmu Pertanian Kopertis Wil.I. 4 (1): 11-17.

Sitohang, N. 2008. Perbanyakan Tunas Pisang Barangan (Musa paradisiaca L.) dalam Media MS dengan Penambahan BAP. Laporan Penelitian. Fakultas Pertanian, Universitas Katolik Santo Thomas Sumatera Utara Medan.

Yusnita. 2003. Kultur Jaringan. Cara Memperbanyak Tanaman Secara Efisien. Agromedia Pustaka. Jakarta. 